\title{
AN EXAMINATION OF THE STUDY ABROAD ADVISING PROCESS IN A UNIVERSITY CONTEXT
}

For this qualitative case study, the aim was to better understand what informs study abroad advising practices from the perspective of the advisor and to examine these practices for evidence of developmental advising using Crookston's (1972) developmental advising framework. This study significantly contributes to the very limited research that is available on advising for study abroad. Because of its limited nature, much of the review of the literature for this study centers on research in the field of academic advising, a closely related field, rather than study abroad advising. Five study abroad advisors at the University of Missouri participated in this study. The data were collected through in-depth interviews, written reflections, and video recorded advising appointments.

There are four distinct themes that inform study abroad advising practices: relevant experiences, formal training, resources, and professional experience. In addition, there are elements of developmental advising practiced by the advisors in this study, including abilities, rewards, maturity, responsibility, and relationships. The implications for future research include studies related to the student perspective on developmental advising, longitudinal studies, student outcomes, and evaluation of advising practices within the study abroad context. As for practical implications, this study can help inform training of study abroad advisors as well as student peer advisors; potentially increase the diversity of the study abroad population by having advisors utilize personal identity to build relationships with students; and, may serve to justify curricular changes within student affairs degrees to include student advising, which is currently lacking in many master's level programs. 